\title{
A Arquitetura da Moradia Estudantil da Unicamp
}

\section{Giovana Bertazzoni De Martino (IC)}

\section{Resumo}

Essa pesquisa visa apresentar a relação entre o processo de projeto da Moradia Estudantil da Unicamp com o processo histórico e os diversos agentes sociais envolvidos (arquitetos, discentes e representantes da Universidade), levando em consideração como esses processos refletiram no projeto final e na sua implantação.

Moradia Estudantil, Arquitetura Moderna, Técnica Construtiva.

\section{Introdução}

Garrido $^{1}$ (2012) considera a Moradia Estudantil como um dos ambientes que enriquecem a experiência Universitária, complementando os espaços tradicionais da Universidade, como laboratórios e salas de aula. Dessa forma, esta pesquisa buscou entender como isso reflete no projeto arquitetônico da Moradia Estudantil da Unicamp, visando, como objetivo geral traçar o histórico da implantação da Moradia Estudantil da Unicamp, especialmente sua implantação, o processo de projeto, o projeto de arquitetura. Com isso, portanto, procurou-se compreender os princípios programáticos que nortearam a adoção do partido arquitetônico e o sistema construtivo adotado, bem como a atuação dos diversos agentes sociais envolvidos, tais como arquitetos, discentes e representantes da Universidade.

\section{Resultados e Discussão}

A partir da revisão bibliográfica e das visitas realizadas ao local, foi possível perceber que a moradia apresenta três características principais. A primeira, o movimento estudantil TABA, considerado um dos mais organizados da história da Universidade que deu início às negociações com a reitoria. O segundo aspecto é o LabHab, Laboratório de Habitação da Unicamp, que não somente desenvolveu uma tecnologia de construção, inovadora para a época, como também foi o responsável pelo envolvimento do arquiteto Joan Villá no projeto. O terceiro ponto é o processo de projeto participativo, no qual o usuário final participa ativamente das discussões e decisões conjuntamente com o arquiteto. Esses aspectos combinados, somados ao momento político e às questões financeiras refletem na arquitetura projetada e construída e caracteriza a
Moradia Estudantil como o espaço que conhecemos atualmente.

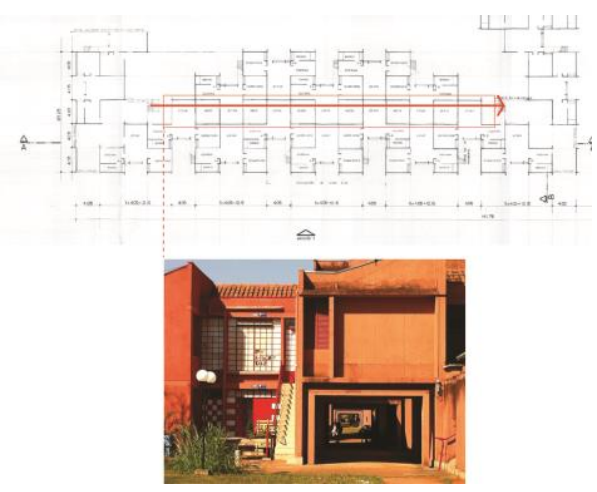

Figura 1. Esquema comparando a construção existente e o que foi projetado.

\section{Conclusões}

Primeiramente, $\mathrm{o}$ desenvolvimento do projeto arquitetônico da Moradia Estudantil da Unicamp mostra que uma boa relação entre arquiteto e usuário é fundamental para uma maior aceitação e identidade das pessoas com o espaço.

Além disso, a pesquisa apontou discussões que continuam fazendo parte da realidade da vida Universitária vinte anos depois, como o déficit de habitações e relação da Universidade com a cidade.

\section{Agradecimentos}

À professora e orientadora Ana Maria de Goes Monteiro pela oportunidade, entusiasmo e paciência em todo o processo dessa pesquisa. À Unicamp, ao PIBIC e ao CNPq pela concessão da bolsa e pelo incentivo à produção cientifica pelos estudantes de graduação. $E$, à minha família, amigos e companheiro pelo acompanhamento e motivação .

${ }^{1}$ Garido, E. N,. Tese de Doutorado: "Moradia Estudantil e formação do(a) estudante universitário(a)". Unicamp, São Paulo, 2012. 